DOI: 10.33184/YVDK-2021-04-30.4

Л.Ч. Латыпова (доц. БашГУ, г. Уфа)

\title{
ПЕРЕВОД РЕКЛАМНОГО ТЕКСТА (НА ПРИМЕРЕ АНГЛОЯЗЫЧНЫХ РЕКЛАМНЫХ СЛОГАНОВ)
}

Статья посвящена рассмотрению особенностей рекламного текста, в частности, его компонента - рекламного слогана. А также в ней анализируются способы перевода рекламных слоганов известных брендов.

Ключевые слова: рекламный слоган, стилистические приемы, способы перевода.

The article examines the peculiarities of advertising text, namely, one of its components - advertising slogans. It also studies various ways of their translation.

Key words: advertising slogan, stylistic devices, ways of translation.

В современном мире, наполненной рекламой, в условиях глобализации и непрерывного обмена товарами и услугами между странами, умение создавать оригинальные, понятные, легко запоминающиеся тексты, способные привлечь внимание потенциального потребителя, становится все более востребованным и объясняет причину интереса рекламистов к различным языковым средствам выразительности в рекламном тексте. Ранее реклама рассматривалась только экономическими и маркетинговыми науками, но теперь она все чаще становится объектом исследования гуманитарных наук, таких как лингвистика, психология, социология, журналистика и др. Этой теме посвящено множество трудов по лингвистике, но тема попрежнему остается актуальной, так как многообразие подходов к ее рассмотрению вовсе не исчерпано, напротив, есть еще достаточное количество неосвещенных вопросов.

«Рекламный текст - сложное семиотическое целое, представляющее собой свободную - как линейную, так и нелинейную - последовательность знаковых единиц, 
максимально приспособленное для выполнения главной задачи продвижения на рынок рекламируемого продукта» [Харлашкина, 2016: 69]. Текст рекламы должен соответствовать ряду требований, а именно, отличаться простотой, четкостью, оригинальностью, образностью, быть запоминающимся, отражать специфику речи и психологию целевой аудитории.

Важнейшей функцией современного рекламного текста является коммуникативная функция, и в задачи переводчика входит ее адекватная передача на переводной язык. При переводе оригинала рекламного текста на другой язык необходимо учитывать целый ряд факторов: цель рекламного сообщения, языковые качества текста оригинала, общая психологическая и этическая характеристика потенциального потребителя, индивидуальные особенности и культурные возможности языка перевода, культурные реалии страны переводного языка, а также много других лингвистических и экстралингвистических факторов.

В самой структуре текста рекламы можно выделить несколько компонентов: это заголовок рекламы, ее подзаголовок, основной рекламный текст, ктематоним (название) и слоган. В настоящем исследовании нас особенно интересует рекламный слоган, так как именно он, являясь неотъемлемой частью рекламный компании, определяет политику компании в отношении определенного товара и целевой аудитории, и позволяет кратко, емко рассказать о товаре потребителю. Цель данной статьи - изучить виды и способы перевода различных рекламных слоганов с английского языка на русский язык. Материалом исследования послужили рекламные слоганы английских и американских компаний, пришедших на российский рынок. Среди способов перевода, согласно классификации, предложенной В.Н. Комиссаровым, были отмечены лексические, грамматические и комплексные лексико-грамматические трансформации, примененные переводчиками для достижения адекватности перевода. Обратимся непосредственно к анализу единиц, отобранных методом сплошной выборки.

Для создания эффективной рекламы ее создатели часто прибегают к различным языковым средствам - стилистическим приемам. Среди самых распространенных приемов можно назвать каламбур (игру слов), аллитерацию, рифму, повторы, 
синтаксический параллелизм, графон, использование окказионализмов, которые создают значительные трудности при переводе таких единиц. Основной целью переводчика при этом является сохранение маркетинговой и художественной ценности рекламного текста. Не всегда возможно использовать тот же самый стилистический прием, что и в оригинале. «Задача переводчика состоит в том, чтобы получившийся в результате русский слоган был столь же удачен с художественной точки зрения, что и исходная фраза» [Радько, 2012: 111].

Удачным со стилистической точки зрения, по нашему мнению, является перевод рекламного слогана компании LG: «Digitally Yours», переведенный как «Цифренно Ваш». Слоган был образован по аналогии с выражением fully yours - искренне ваш. Переводчики воспользовались дословным переводом (грамматическая трансформация) и сумели сохранить задумку оригинала, использовав окказионализм циифренно, созвучный со словом искренне.

В оригинале рекламы крупной американской авиакомпании US Airways - «Fly With US» заложен стилистический прием игры слов, основанный на употреблении слов us и US в одном контексте одновременно. При переводе данного слогана был применении дословный перевод (грамматическая трансформация), что передает его суть, но, к сожалению, игра слов была утеряна - «Летай с нами».

В социальной рекламе Фонда по защите амазонских лесов: «American Forests. Global REleaf» употребляется игровая омофония с графическим выделением, актуализирующая и предмет защиты - leaf «лист», и результат деятельности nомощь «relief». И снова видим пример дословного перевода «Американские леса. Глобальная помощь». Оригинальная игра слов утеряна в силу особенностей переводного языка.

Сознательное нарушение написания слова fit в 3м лице ед.ч., т.е. стилистический прием графон, наблюдаем в рекламе популярного крекера Ritz Crackers: «Nothing fitz like a Ritz». Графон используется для создания рифмы - действенного средства запоминания рекламного текста. «Ничто так не подходит как Ритз», как видим, прием добавления, выбранный переводчиком, не сумел передать всю стилистическую глубину оригинала, утеряны рифма и графон. 
Еще одним примером использования графона в рекламном тексте служит слоган фармацевтической компании REL Maryland Pharmaceutical: "RELy on REL for real RELief' - «Положитесь на $R E L »$. Использование прописной буквы сочетается с корневым повтором в словах rely, REL, real, relief. Аллитерация, а также выделение названия препарата создают выразительную языковую игру. При переводе употреблен прием опущения. В переводе языковая игра утеряна.

«The coffee-er coffee»- «Лучше других». Это реклама Savarin Coffee, в которой использован окказионализм при помощи добавления суффикса сравнительной степени. Намек на превосходящие по сравнению с конкурентами качества продукта. Здесь при переводе использован прием целостного преобразования. Сохранена превосходная степень, но утерян оригинальный стилистический прием тавтологии.

В рекламе іМас компании Apple «iThink, Therefore iMac» использована аллюзия - отсыл к известной фразе Рене Декарта "I think, therefore I am" (Cogito ergo sum). - «Я мыслю, значит, пользуюсь компьютером Mac. Apple». Помимо аллюзии здесь применены игра слов и графический прием. Но в переводе приемом целостного преобразования передан лишь смысл, но не стилистика оригинального рекламного текста.

Иногда переводчику удается сохранить игру слов в тексте, как в переводе слогана пива Pilsner Urquell: «For some the essence is to see, for others to see the essence» - «Для одних главное увидеть, для других - увидеть главное». Создатели текста использовали каламбур, английское слово essence - многозначно, второе значение подчеркивает особенность бренда ориентированность на определенную категорию потребителей, серьезных, требовательных. Семантическая структура многозначного русского слова «главное» во многом схожа с английским, что и позволило перевести слоган близко к оригиналу, с сохранением значений и порядка слов (дословный перевод).

В рекламе чипсов Pringles: «Once you POP, you can't STOP!» видим два стилистических приема: рифму и ономатопею. Слово "рор" имитирует звук хлопка открываемой крышки, который можно понять буквально - однажды открыв крышку, вы съедите все чипсы в банке. Переводчик сумел сохранить рифму и 
основной посыл слогана: «Попробовав раз, ем и сейчас». При переводе использован прием целостного преобразования.

Анализ рекламного слогана, как важнейшего компонента рекламного текста, охватывает целый ряд вопросов. Наиболее актуальными из них, на наш взгляд, являются следующие проблемы: изучение роли языка как средства воздействия на получателя сообщения, изучение языка рекламного слогана, «особенности употребления различных языковых средств в целях воздействия на потенциального покупателя, лексические и прагматические особенности функционирования языка слогана в рекламном тексте» [Харлашкина, 2016: 70]. Способы перевода рекламного способа также входят в список актуальных проблем, связанных с изучением данного явления. Представленный краткий обзор примеров перевода различных рекламных слоганов показывает, что успешная передача всех лексических и стилистических компонентов оригинала зачастую невозможна или затруднена, и это объясняется различиями в грамматическом и лексическом строе двух языков. Прагматический аспект перевода при этом играет большую роль и переводчику важно передать замысел создателя рекламы, его коммуникативную интенцию.

\section{ЛИТЕРАТУРА}

1. Радько Д.Н. Стратегии адаптации рекламного текста (на примере англоязычных рекламных слоганов). Язык и культура. Сборник статей XXII Международной научной конференции/Министерство образования Российской Федерации, Томский государственный университет. 2012, C.107-111.

2. Харлашкина М.Ю. Теоретические основы исследования функций рекламного слогана как основного вербального компонента рекламного текста актуальные проблемы современной филологии и методики преподавания языка /Материалы VIII международной научно-практической Интернет-конференции. 2016. Издательство: Орловский государственный университет экономикии торговли (Орел) - С. 66-72.

3. Лучшие рекламные слоганы за всю историю! https:/yvision.kz/post/81559 (дата обращения: 15.04.2021).

4. Рекламные слоганы: мифы и реальность. URL: http://www.worldeconomy.nu (дата обращения: 20.04.2021).

(С) Латьпова Л.Ч., 2021 г. 